\title{
Papers
}

\section{A survey of general practitioners' views on autopsy reports}

\author{
Samantha Karunaratne, Emyr W Benbow
}

\begin{abstract}
Aims-To study the views of general practitioners on the quality and utility of autopsy reports, and on autopsies in general.

Methods-For a period of six months, a questionnaire was enclosed with each autopsy report sent to a general practitioner from the mortuary at Manchester Royal Infirmary.

Results-Most (93.3\%) general practitioners found the autopsy report useful, and many $(66.7 \%)$ thought the bereaved relatives would do so too. However, only a minority $(25.2 \%)$ would discuss the report with the relatives. A considerable proportion $(20.0 \%)$ found the cause of death surprising, and a significant number $(10.4 \%)$ felt the report would modify their future clinical practice. There was approval of autopsies in general, with most (88.6\%) agreeing that autopsies reveal lesions not detected in life, and many (74.4\%) indicating that loss of the autopsy would impair severely the monitoring of clinical standards.

Conclusions-General practitioners appreciate autopsy reports, which may have a significant impact on clinical practice. Autopsy reports provide both case audit and information for relatives. (F Clin Pathol 1997;50:548-552)
\end{abstract}

Keywords: autopsy; family practice; grief; medical audit

Autopsy rates have been declining gradually over several decades in many parts of the world ${ }^{1-5}$ with few exceptions, ${ }^{6-8}$ despite the procedure's well established role in disclosing clinical diagnostic inaccuracy. ${ }^{9}{ }^{10}$ Many factors underlie this decline, but one of the most potent is likely to be the attitudes of both health care professionals and the general public. Other workers have studied the views of the general public, ${ }^{11-15}$ embalmers and funeral directors, ${ }^{16} 17$ medical students, ${ }^{18-23}$ hospital clinicians, ${ }^{24-29}$ and pathologists. ${ }^{25}{ }^{30-32}$ Previous studies have examined the distribution of autopsy reports to general practitioners, the understanding that general practitioners have of their access to autopsy services and of which cases should be referred to the coroner, and general practitioners' overall views on autopsies. ${ }^{33-36}$ Our study concentrates on general practitioners' views on the utility of individual reports.

\section{Methods}

Reports on autopsies carried out by the adult autopsy service at Manchester Royal Infirmary are sent routinely to general practitioners. From 1 May to 30 October 1995, each was accompanied by a questionnaire, an explanatory letter, and a self-addressed return envelope. The questionnaire included a brief section on how the subject's death had been reported to the general practitioner, and a longer section on the characteristics of the report and the value of its content. A few questions on the respondent's views on autopsies in general were taken from a previous study. ${ }^{20}$ Some of the responses were made on closed categorical scales (tables 1-3), but most were made on five point Likert scales (tables 4 and 5). The last page of the questionnaire was an open-ended invitation to comment on the content of any of the preceding closed questions. Numerical data was analysed with the software package SPSS (Chicago, Illinois, USA). The first 20 returns were intended to be a pilot study, but scrutiny of these revealed that there were no difficulties with the design of the study that required any remedy.

\section{Results}

Of 395 questionnaires sent out, 256 accompanied reports on patients who had died in the community and who were subjected to autopsy at the request of the coroner. Of the remaining 139 cases, 129 were coroner's autopsies carried out on patients who had died in hospital; only 10 were clinical interest autopsies, and none of these had been requested by general practitioners. One hundred and thirty five $(34.2 \%)$ were returned with usable data; eight more were returned blank because they had been sent to the wrong general practitioner, or because the patient's notes were no longer available, despite the fact that all these reports were sent out within three days of autopsy. The completed returns indicated that $24 \%$ of respondents had seen the patient during the last week of life, $32 \%$ in the last month, $30 \%$ in the last year, and $9 \%$ more than a year before death; $1 \%$ could not remember and $4 \%$ did not respond to this question. Very few were present at 
Table 1 Responses to the question "When did you first know of the patient's death?"

\begin{tabular}{lc}
\hline & Number $(\%)$ \\
\hline Present at death & $1(0.7)$ \\
Within one hour & $14(10.4)$ \\
Within one day & $71(53.3)$ \\
Within one week & $35(25.9)$ \\
In over a week & $9(6.7)$ \\
No response & $5(3.7)$ \\
\hline
\end{tabular}

Table 2 Responses to the question "How did you find out about the death?"

\begin{tabular}{lc}
\hline & Number (\%) \\
\hline Own observations & $3(2.2)$ \\
Relatives & $29(21.5)$ \\
Police & $25(18.5)$ \\
Hospital clinical personnel & $29(21.5)$ \\
Mortuary staff & $14(10.4)$ \\
Other sources & $28(20.7)$ \\
No response & $7(5.2)$ \\
\hline
\end{tabular}

Table 3 Summarised responses to the question "How many days, from the patient's death, has it taken for this report to come to you?"

\begin{tabular}{lc}
\hline & Number (\%) \\
\hline Within one day & $1(0.9)$ \\
Within one week & $63(46.6)$ \\
Within a fortnight & $43(31.8)$ \\
Within a month & $6(4.4)$ \\
Over a month & $3(2.2)$ \\
No response & $19(14.1)$ \\
\hline
\end{tabular}

death, but the majority knew within one day that death had occurred. A few were not aware of the death for over a week, although at least a proportion of these general practitioners were on annual leave when death had occurred (table 1). They were first informed of the deaths by a variety of agents, including clinical personnel at the hospital, relatives of the deceased, the police, and mortuary staff (table 2). The autopsy report had reached the general practitioner within one week in nearly half the cases, and very few took over a month (table 3); again, the longer delays were associated with the general practitioners' absence. Table 4 indicates respondents' views on a number of aspects of the autopsy report itself, and table 5 is concerned with their views on the autopsy in general.

\section{Discussion}

Our mortuary has a public mortuary function, serving the City of Manchester, as well as being the hospital mortuary for Manchester Royal Infirmary. With the coroner's permission, we routinely send copies of our autopsy reports to general practitioners, but until this study, we had no understanding of whether this practice was valued by the recipients. There is an enormous literature on the potential benefits of autopsy reports ${ }^{37}$ but this relates almost exclusively to the value of the autopsy in a hospital setting.

We have no personal information about the recipients of our questionnaires, apart from

Table 4 Responses to attitude statements relating to the autopsy reports and their contents

\begin{tabular}{|c|c|c|c|c|c|c|c|c|}
\hline & Attitude statement & Strongly agree & Agree a little & $\begin{array}{l}\text { Neither agree } \\
\text { nor disagree }\end{array}$ & $\begin{array}{l}\text { Disagree a } \\
\text { little }\end{array}$ & $\begin{array}{l}\text { Strongly } \\
\text { disagree }\end{array}$ & $\begin{array}{l}\text { Mean } \\
\text { rank* }\end{array}$ & No response \\
\hline 1 & I found the report useful & $102(75.6)$ & $24(17.8)$ & $7(5.2)$ & $1(0.7)$ & $1(0.7)$ & 1.3 & 0 \\
\hline 2 & $\begin{array}{l}\text { I anticipate the patient's relatives will find } \\
\text { the report useful }\end{array}$ & $58(45.0)$ & $32(28.4)$ & $25(19.4)$ & $5(3.9)$ & $9(7.0)$ & 2.3 & 6 \\
\hline 3 & $\begin{array}{l}\text { I was surprised that an autopsy was carried } \\
\text { out }\end{array}$ & $6(4.5)$ & $4(3.0)$ & $10(7.5)$ & $5(3.7)$ & $109(81.3)$ & 4.5 & 1 \\
\hline 4 & I found the report to be too long & $10(7.5)$ & $18(13.4)$ & $23(17.2)$ & $36(26.9)$ & $47(35.1)$ & 3.7 & 1 \\
\hline 5 & The report will modify my future clinical & $4(3.0)$ & $10(7.5)$ & $51(38.1)$ & $20(14.9)$ & $49(36.6)$ & 3.7 & 1 \\
\hline 6 & $\begin{array}{l}\text { I found it difficult to find the statement of } \\
\text { the cause of death } \\
\text { The circumstances leading to the patient's }\end{array}$ & $6(4.5)$ & $10(7.5)$ & $14(10.5)$ & $20(15.0)$ & $83(62.4)$ & 4.2 & 2 \\
\hline 8 & $\begin{array}{l}\text { 1he circumstances leading to the patient's } \\
\text { death were clearly summarised } \\
\text { I have discussed the report with the }\end{array}$ & $68(50.4)$ & $41(30.4)$ & $13(9.6)$ & $8(5.9)$ & $5(3.7)$ & 1.8 & 0 \\
\hline 9 & $\begin{array}{l}\text { relatives or intend to do so } \\
\text { The autopsy report was the first indication }\end{array}$ & $13(10.4)$ & $21(16.8)$ & $32(25.6)$ & $11(8.8)$ & $48(38.4)$ & 3.5 & 10 \\
\hline 10 & $\begin{array}{l}\text { I got that my patient had died } \\
\text { The autopsy report was the first indication } \\
\text { I got from the hospital that my patient had }\end{array}$ & $12(8.9)$ & 0 & $4(3.0)$ & $3(2.2)$ & $116(85.9)$ & 4.6 & 0 \\
\hline 11 & $\begin{array}{l}\text { died } \\
\text { The autopsy report was the first indication }\end{array}$ & $20(15.0)$ & $1(0.8)$ & $4(3.0)$ & $4(3.0)$ & $105(78.2)$ & 4.3 & 1 \\
\hline 12 & $\begin{array}{l}\text { I got of how my patient had died } \\
\text { The autopsy report was the first indication } \\
\text { I got from the hospital of how my patient } \\
\text { had died }\end{array}$ & $58(43.3)$ & $17(12.7)$ & $7(5.2)$ & $9(6.7)$ & $43(32.1)$ & 2.7 & 1 \\
\hline $\begin{array}{l}13 \\
14\end{array}$ & $\begin{array}{l}\text { I wish I had never seen the report } \\
\text { The cause of death given on the report was }\end{array}$ & $\begin{array}{c}54(41.2) \\
3(2.2)\end{array}$ & $\begin{array}{l}9(0.9) \\
1(0.7)\end{array}$ & $9(5.3)$ & $\begin{array}{l}9(0.9) \\
5(3.7)\end{array}$ & $\begin{array}{r}52(39.7) \\
117(86.7)\end{array}$ & $\begin{array}{l}3.0 \\
4.7\end{array}$ & $\begin{array}{l}4 \\
0\end{array}$ \\
\hline 15 & $\begin{array}{l}\text { a complete surprise to me } \\
\text { The patient's death was expected }\end{array}$ & $\begin{array}{l}17(12.8) \\
14(10.4)\end{array}$ & $\begin{array}{l}10(7.5) \\
18(13.3)\end{array}$ & $\begin{array}{l}18(13.5) \\
27(20.0)\end{array}$ & $\begin{array}{l}15(11.3) \\
20(14.8)\end{array}$ & $\begin{array}{l}73(54.9) \\
56(41.5)\end{array}$ & $\begin{array}{l}3.9 \\
3.6\end{array}$ & $\begin{array}{l}2 \\
0\end{array}$ \\
\hline 16 & $\begin{array}{l}\text { The reason that the autopsy was carried } \\
\text { out is clear to me }\end{array}$ & $114(84.4)$ & $10(7.4)$ & $2(1.5)$ & $3(2.2)$ & $6(4.4)$ & 1.3 & 0 \\
\hline 17 & $\begin{array}{l}\text { The autopsy report is written in a helpful } \\
\text { manner }\end{array}$ & $89(65.9)$ & $35(25.9)$ & $8(5.9)$ & $2(1.5)$ & $1(0.7)$ & 1.4 & 0 \\
\hline 18 & $\begin{array}{l}\text { The report makes it difficult to determine } \\
\text { the relation between clinical observations } \\
\text { and pathological findings }\end{array}$ & $5(3.8)$ & $7(5.3)$ & $26(19.5)$ & $36(27.1)$ & $59(44.4)$ & 4.0 & 2 \\
\hline 19 & The report contains too much jargon & $2(1.5)$ & $5(3.8)$ & $23(17.3)$ & $27(20.3)$ & $76(57.1)$ & 4.3 & 2 \\
\hline 20 & I found the report interesting & 77 (57.9) & $41(30.8)$ & $9(6.8)$ & $3(2.3)$ & $3(2.3)$ & 1.6 & 2 \\
\hline 21 & $\begin{array}{l}\text { The patient's death was a complete } \\
\text { surprise to me }\end{array}$ & $38(28.1)$ & $17(12.6)$ & $21(15.6)$ & $20(14.8)$ & $36(26.7)$ & 3.0 & 3 \\
\hline
\end{tabular}

ॠMean ranks are calculated by ascribing a score of 1 to strongly agree, 2 to agree a little, etc.

Numbers in parentheses are percentages, calculated after exclusion of non-responders from the denominator. 
their names and practice addresses; therefore, we cannot make the conventional claims that the views of those who responded are likely to be representative of those who did not. We chose not to send follow up letters to non-respondents, which largely explains the low response rate, because we wanted the respondents' immediate responses to the reports, and because the pilot stage showed that some respondents felt unable to fill out the questionnaire after the patients' notes had been returned to the Family Health Services Authority. Surveys of general practitioners are notorious for producing low response rates. ${ }^{38}$

Even with a low return rate, we feel that the findings are important, and support our view that the distribution of autopsy reports to general practitioners is worthwhile. For instance, 102 of the $135(75.6 \%)$ respondents agreed strongly that they found the report useful, and even if we assume that all the non-responders held the contrary view, this would still indicate a success rate of $25.8 \%$ (102 of 395). Similarly, even the small proportion who feel the report may change their clinical practice is, in our view, ample justification for the generation and distribution of one extra copy of each report.

We did a follow up survey by telephone of those who had indicated that they might change their clinical practice, and a number of interesting insights were gleaned. Some could not be contacted, but we can guess the response of the general practitioner who reintroduced warfarin into a psychotic patient's regimen after discharge from hospital (without reinstituting monitoring of prothrombin times despite previous poor anticoagulant control) to learning of the patient's death from an acute subdural haemorrhage. Comments by those who could be contacted were mainly about policy issues, rather than specific features of management. For instance, one general practitioner indicated that an intention to institute regular home visits to elderly patients who did not attend the surgery was crystallised into action by our finding of an unanticipated bronchial carcinoma in such a patient, and another signalled an intent to chase up younger non-attenders after a 38 year old man died of hypertensive heart disease after failing to attend follow up appointments. More specific changes are illustrated by a general practitioner in a deprived inner city area who indicated that an autopsy report had alerted him to a better understanding of the possible sites of sepsis in intravenous drug abusers.

The majority of respondents anticipated "that the relatives will find the report useful", which contrasts with the observation that only $27.2 \%$ had discussed, or intended to discuss, the report with relatives. Several respondents indicated that their lack of intention to discuss the report with relatives was because they had no means of contacting them, or that they felt inhibited about contacting individuals on the lists of other general practitioners. Others may have been inhibited by the standard admonition that appears on each report, at the request of the coroner, that the content should not be disclosed to a third party without his permission. Anecdotal evidence suggests that some coroners prevent the dissemination of reports through any route, ${ }^{39}$ even though the Coroners' Society takes the view that it is appropriate for coroners to forward copies of autopsy reports to general practitioners who provide a stamped, self-addressed envelope. Relatives have no statutory rights to details, and so a general practitioner in possession of a copy of an autopsy report may be in an invidious position when asked for details. Autopsies may reveal findings relevant to the future wellbeing of surviving relatives, ${ }^{40}$ and in such cases the general practitioner may feel a moral responsibility to pass on such information even when this is in conflict with the legal requirement of confidentiality. We can only suggest that general practitioners concerned by such conflicts should explain the situation to the coroner, but that they should be prepared for refusal to divulge details to relatives if an inquest is to be held, at least until the hearing is over.

The utility of the autopsy report to relatives may, therefore, be compromised by the structure of the health care system and by the requirements of the legal system, a difficulty which might be addressed if and when a long overdue overhaul of the legal aspects of death certification takes place. ${ }^{41}$ This is an important issue because accurate information about a relative's death, such as that derived from autopsy, can help families deal with grief. ${ }^{42}{ }^{43}$ In general, hospital staff make few systematic

Table 5 Responses to attitude statements about the autopsy in general

\begin{tabular}{|c|c|c|c|c|c|c|c|c|}
\hline & Attitude statementst & $\begin{array}{l}\text { Strongly } \\
\text { agree }\end{array}$ & Agree a little & $\begin{array}{l}\text { Neither agree } \\
\text { nor disagree }\end{array}$ & $\begin{array}{l}\text { Disagree a } \\
\text { little }\end{array}$ & $\begin{array}{l}\text { Strongly } \\
\text { disagree }\end{array}$ & $\begin{array}{l}\text { Mean } \\
\text { rank }^{\star}\end{array}$ & No response \\
\hline 22 & $\begin{array}{l}\text { The only justification for autopsy is the } \\
\text { suspicion of serious crime }\end{array}$ & $10(7.6)$ & $6(4.6)$ & $10(7.6)$ & $20(15.3)$ & $85(64.9)$ & 4.2 & 4 \\
\hline 23 & $\begin{array}{l}\text { The autopsy often reveals pathological } \\
\text { processes not detected in life }\end{array}$ & $79(59.4)$ & $39(29.3)$ & $6(4.5)$ & $5(3.8)$ & $4(3.0)$ & 1.7 & 2 \\
\hline 24 & $\begin{array}{l}\text { Autopsies can be interesting even if no } \\
\text { unanticipated findings are made }\end{array}$ & $50(37.9)$ & $52(39.4)$ & $18(13.6)$ & $7(5.3)$ & $5(3.8)$ & 2.0 & 3 \\
\hline 25 & $\begin{array}{l}\text { The autopsy is a thoroughly unpleasant } \\
\text { procedure }\end{array}$ & $17(12.8)$ & $26(19.5)$ & $38(28.6)$ & $23(17.3)$ & $29(21.8)$ & 3.1 & 2 \\
\hline 26 & $\begin{array}{l}\text { Without the autopsy, our ability to monitor } \\
\text { standards of clinical practice would be } \\
\text { impaired severely }\end{array}$ & $63(47.7)$ & $35(26.5)$ & $18(13.6)$ & $11(8.3)$ & $5(3.8)$ & 1.9 & 3 \\
\hline 27 & $\begin{array}{l}\text { The autopsy represents unacceptable } \\
\text { mutilation of a human being }\end{array}$ & $6(4.5)$ & $9(6.8)$ & $19(14.3)$ & $25(18.8)$ & $74(55.6)$ & 4.1 & 2 \\
\hline
\end{tabular}

Numbers in parentheses are percentages, calculated after exclusion of non-respondents from the denominator.

$\star$ Mean ranks are calculated by ascribing a score of 1 to strongly agree, 2 to agree a little, etc.

$\dagger$ These statements are based on items in a previous study. ${ }^{20}$ 
Table 6 Cause of death on reports where respondents strongly agreed with the statement "the cause of death was a complete surprise to me"

\begin{tabular}{|c|c|c|}
\hline Case & $\begin{array}{l}\text { Sex and age (years) of } \\
\text { patients }\end{array}$ & Cause of death \\
\hline $1-7$ & $\begin{array}{l}\text { F 77; M 80; M 75; M 72; } \\
\text { M 56; M 52; M } 36\end{array}$ & Complications of coronary artery atheroma \\
\hline 8 & M 69 & $\begin{array}{l}\text { Pulmonary embolism associated with deep vein } \\
\text { thrombosis }\end{array}$ \\
\hline 9 & M 36 & Mitral valve prolapse \\
\hline 10 & F 60 & Acute subdural haemorrhage; patient on warfarin \\
\hline 11 & M 73 & $\begin{array}{l}\text { Subarachnoid haemorrhage associated with berry } \\
\text { aneurysm }\end{array}$ \\
\hline 12 & F 37 & Bronchopneumonia; carcinoma of the bronchus \\
\hline 13 & F 84 & Primary malignant tumour of the liver \\
\hline 14 & M 37 & Overdose of dothiepin \\
\hline
\end{tabular}

No details available for three cases because of obliteration of case numbers on returned questionnaires.

efforts to provide such assistance by discussing autopsy results with relatives, although paediatricians are often an exception. ${ }^{44}{ }^{45}$ Pathologists may contribute to postautopsy conferences with bereaved relatives, especially the bereaved parents of children, ${ }^{44}{ }^{46} 47$ but this is not yet standard practice in the UK. In a service like ours, where the majority of the autopsies are on subjects who died outside hospital, the general practitioner represents the only realistic route of disseminating autopsy results to relatives.

In this hospital, there is a centralised office (known locally as the RMO's Office), which deals with issues such as death certification and liaison with the Coroner's Office, but it does not concern itself with subjects who die outside of the hospital. Because of this, and to facilitate rapid completion of autopsies, the mortuary staff contact general practitioners to determine whether they feel able to issue Death Certificates in such cases. By this means they provide the general practitioner with the first indication of the patient's death in $10.4 \%$ of cases, and in another $8.9 \%$ receipt of the autopsy report appears to perform the same function. This last figure is surprising, as the police, the mortuary staff, or a member of the RMO's Office staff telephone general practitioners' surgeries soon after each death. We can think of no simple explanation, apart from poor communication within surgeries, but our finding coincides with a previous observation that general practitioners often learn of their patients' deaths only after a delay. ${ }^{48}$

One of the benefits of autopsy is its function in audit, ${ }^{1037}$ a feature supported by the fact that $40.7 \%$ of respondents were surprised by the patient's death, and $20.3 \%$ were surprised by the cause of death. Table 6 provides details of some of the cases where general practitioners were surprised by the cause of death. Almost all cases were coroner's cases, recently shown to reveal many clinically silent lesions. ${ }^{49}$ Others have found that general practitioners have an imperfect understanding of which cases should be reported to the coroner, ${ }^{36}$ which correlates with our observation that $7.5 \%$ were surprised that autopsy had been carried out, and that only $91.8 \%$ understood why. Overall, general practitioners agree that the autopsy reveals diagnoses not detected in life, and that it has a role outside the investigation of crime, including the audit of clinical practice. They tended to disagree with the view that autopsies repre- sent unacceptable mutilation, and to agree that they can be interesting even if they demonstrate no unanticipated lesions.

This study was conceived initially as an audit of the quality of our reports. These are full reports, typically consisting of patient identification data, a list of the pathological lesions, a summary of the clinical presentation, a description of the findings, brief explanatory comments that may correlate clinical and pathological observations, and a cause of death in the standard World Health Organisation format. This format reflects the recommendations of the Royal College of Pathologists. ${ }^{50}$ One or more of these sections may be omitted at the discretion of the pathologist, for example when no clinical history is available. It is of concern that $12.8 \%$ of respondents found the statement of cause of death difficult to find, and that $20.9 \%$ found the report too long; one respondent requested that a condensed version be produced especially for general practitioners. However, very few disagreed with the contention that the report was written in a helpful manner, and few believed it contained too much jargon.

We know from informal discussions that many other autopsy services send copies of reports to general practitioners routinely, whereas some are forbidden to do so by their coroner. We even have an example where a coroner will not allow reports to be distributed within the hospital where the patient died. Our study suggests that general practitioners appreciate autopsy reports, and that they may have a significant impact upon practice, both as a form of case audit and feedback for relatives. Distribution of autopsy reports to general practitioners should become the norm, and legal barriers to this dissemination should be demolished.

We thank Margaret Barringer, Anita Brookes, Irene Bohanna, and Lisa Ward for duplicating and distributing the questionnaires.

1 Waldron HA, Vickerstaff L. Necropsy rates in the United Birmingham Hospitals. BMF 1975;ii:326-8. 2 Cameron HM, McGoogan E, Clarke J, Wilson BA. Trends 1577-80.

3 Start RD, McCulloch TA, Benbow EW, Lauder I, Underwood JCE. Clinical necropsy rates during the 1980 s: the continued decline. $\mathcal{F}$ Pathol 1993;171:63-6.

4 Eriksson L, Sundström C. Decreasing autopsy rate in Sweden reflects changing attitudes among clinicians. Qual Assur Health Care 1993;5:319-23.

5 Nayar R, Mannion C, Weisenberg E. American Society of Clinical Pathologists-Resident Physician Section. Results of autopsy survey (winter 1994-1995). Am f Clin Pathol 1996;105:144-8.

6 Smith RD, Zumwalt RE. One department's experience with increasing the autopsy rate. Arch Pathol Lab Med 1984;108: increasing

7 Champ C, Tyler X, Andrews PS, Coghill SB. Improve your hospital autopsy rate to 40-50 per cent, a tale of two towns. F Pathol 1992;166:405-7.

8 Djaldetti M, Hart J, Yarmolovsky A, Zeidman A, Floru S Gardyn J, et al. Is it possible to improve the autopsy rate? Is f Med Sci 1995;31:436-8.

9 Kingsford DPW. A review of diagnostic inaccuracy. Med $S c i$ Law 1995;35:347-51.

$10 \mathrm{McPhee}$ SJ. The autopsy. An antidote to misdiagnosis. Medicine (Baltimore) 1996;75:41-3.

11 Brown HG. Perceptions of the autopsy: views from the lay public and program proposals. Hum Pathol 1990;21:154-8.

public and program proposals. Hum Pathol $1990,21: 154-8$. of elderly patients. Age Ageing 1993;22:205-8.

13 Sanner MA. In perspective of the declining autopsy rate. Sanner MA. In perspective of the declining autopsy rate.
Attitudes of the public. Arch Pathol Lab Med 1994;118: Attitudes

14 Balic V, Rumboldt Z. Public attitudes toward autopsy, organ donation, and dissection. $\mathcal{F} A M A$ 1995;273:1907. 
15 Start RD, Saul CA, Cotton DWK, Mathers NJ, Underwood JCE. Public perceptions of necropsy. $\mathcal{F}$ Clin Pathol 1995;48 497-500.

16 Heckerling PS, Williams MJ. Attitudes of funeral directors and embalmers toward autopsy. Arch Pathol Lab Med 1992; 116:1147-51

17 Start RD, Dube A, Cross SS, Underwood JCE. Funeral directors, mortuaries and necropsies: implications for necropsy consent rates and the prevention of infection. $\mathcal{F}$ Clin Pathol 1996;49:217-22.

18 Hoda SA, Gerber MA. The value of the autopsy for the 1990s. Hum Pathol 1990;21:980-1.

19 Benbow EW. Medical students' views on necropsies. $\mathcal{f}$ Clin Pathol 1990;43:969-76.

20 Benbow EW. The attitudes of second- and third-year medical students to the autopsy. A survey by postal questionnaire. Arch Pathol Lab Med 1991;115:1171-6.

21 Hoda SA, Horenstein M, Gerber MA. Additional comments on the value of the autopsy for the 1990s. Hum Pathol 1994;25:839-40.

22 Sanner MA. Medical students' attitudes toward autopsy. How does experience with autopsies influence opinion? Arch Pathol Lab Med 1995;119:851-8.

23 Conran P, Nowacek G, Adams T, Smith L. Medical students' attitudes toward the autopsy. Acad Med 1996;71: $681-3$.

24 McGoogan E, Cameron HM. Clinical attitudes to the autopsy. Scott Med f 1978;23:19-22.

25 Cottreau C, McIntyre L, Favara BE. Professional attitudes toward the autopsy. A survey of clinicians and pathologists Am ₹ Clin Pathol 1989;92:673-6.

26 Wilkes MS, Link RN, Jacobs TA, Fortin AH, Felix JC. Attitudes of house officers toward the autopsy. 7 Gen Intern Med 1990;5:122--5.

27 Katz PR, Seidel G. Nursing home autopsies. Survey of physician attitudes and practice patterns. Arch Pathol Lab Med 1990;114:145-7.

28 Harris A, Ismail I, Dilly S, Maxwell JD. Physicians' attitudes to the autopsy. F $R$ Coll Physicians Lond 1993;27:116-18.

29 Hinchliffe SA, Godfrey HW, Hind CRK. Attitudes of junio medical staff to requesting permission for autopsy. Postgrad Med f 1994;70:292-4.

30 Hill RB, Anderson RE. The uses and value of autopsy in medical education as seen by pathology educators. Acad Med 1991;66:97-100

31 Stubbs F, Start RD, Hector-Taylor MJ, Cotton DWK. The attitudes of junior pathologists towards the autopsy. $f$ Pathol 1992;166:413-15.
32 Start RD, McCulloch TA, Silcocks PB, Cotton DWK. Attitudes of senior pathologists towards the autopsy. $\mathcal{F}$ Patho 1994;172:81-4

33 Hunt AC. The necropsy in audit in clinical medicine and other medical specialties. 7 Clin Pathol 1989;42:564-5.

34 Whitty P, Parker C, Prieto-Ramos F, Al-Karusi S. Communication of results of necropsies in North East Thames region. BMF 1991;303:1244-6.

35 Berlin A, Wagstaff R, Bhopal R, Spencer J. Postmortem examinations: general practitioners knowledge, behaviour, and attitudes. BMF 1994;308:1080-1.

36 Start RD, Usherwood TP, Carter N, Dorries CP, Cotton DWK. General practitioners' knowledge of when to refer deaths to a coroner. Br 7 Gen Pract 1995;45:191-3.

37 Hill RB, Anderson RE. The autopsy-medical practice and public policy. Stoneham: Butterworths, 1988.

38 McAvoy BR, Kaner EFS. General practice postal surveys: a questionnaire too far. BMf 1996;313:732-3.

39 Thomas KB, Weller RO. General practitioners and necropsies. BMF 1994;308:1054

40 Bierig JR. A potpourri of legal issues relating to the autopsy Arch Pathol Lab Med 1996;120:759-62.

41 Leadbeatter S, Knight B. Reporting deaths to coroners. BMF 1993;306:1018.

42 Reynolds RC. Autopsies-benefits to the family. $A m \mathcal{F}$ Clin Pathol 1978;69:220-2.

43 McManus BM, Wood SM. The autopsy. Simple thought about the public needs and how to address them. Am $\mathcal{f}$ Clin Pathol 1996;106(suppl 1):S11-14

44 Valdes-Dapena $M$. The postautopsy conference with families. Arch Pathol Lab Med 1984;108:497-8.

45 Dent A, Condon L, Blair P, Fleming P. A study of bereavement care after a sudden and unexpected death. Arch Dis Child 1996;74:522-6.

46 Hirsch CS. Talking to the family after an autopsy. Arch Pathol Lab Med 1984;108:513-14.

47 Hill RB, Anderson RE. The evolving purposes of the autopsy: twenty-first-century values from an eighteenthcentury procedure. Perspect Biol Med 1989;32:223-33.

48 Neville G. Notifying general practitioners about deaths in hospital: an audit. $\mathcal{F} R$ Coll Gen Pract 1987;37:496-7.

49 O'Sullivan JP. The coroner's necropsy in sudden death: an under-used source of epidemiological information. $7 \mathrm{Clin}$ Pathol 1996;49:737-40.

50 Royal College of Pathologists. Guidelines for post morten reports. London: Royal College of Pathologists, 1993. 